\title{
Three-Phase Partitioning OF $\alpha$-Galactosidase From Aspergillus Lentulus: Optimization of System And Characterization of Enzyme
}

\section{a-Galaktozidazin Aspergillus lentulus'dan Üçlü-Faz Ayırımı: Sistemin Optimizasyonu ve Enzimin Karakterizasyonu}

\author{
Derya Çamurlu' $^{1 \oplus}$, Hasan Bayraktar ${ }^{1 \oplus}$, Sennur Çalışkan Özdemir ${ }^{2}$, Ataç Uzel $^{2 \oplus}$, Seçil Önal ${ }^{1 \oplus}$ \\ ${ }^{1}$ Department of Biochemistry, Faculty of Science, Ege University, Bornova, İzmir, Turkey. \\ ${ }^{2}$ Department of Biology, Faculty of Science, Ege University, Bornova, Izmir, Turkey.
}

\section{ABSTRACT}

\begin{abstract}
Three-phase partitioning (TPP) technique is successfully used for the first time for partial purification of $\alpha$-galactosidase from Aspergillus lentulus in single step. The influence of variations in ammonium sulfate concentration, extract to t-butanol ratio and $\mathrm{pH}$ on extraction efficiency of the enzyme are investigated to achieve the highest yield and purity fold. Optimal purification parameters of the system are determined as 55\% (w/v) ammonium sulfate concentration with $1: 1$ ( $\mathrm{v} / \mathrm{v}$ ) ratio of crude extract to t-butanol at pH 5.5. This optimized TPP system gave 5.3 purification fold with $178 \%$ recovery of $\alpha$-galactosidase. The maximum activity was registered at $\mathrm{pH} 6.5$ and $50^{\circ} \mathrm{C}$. $\alpha$-Galactosidase showed a good stability within the temperature range of $25-60^{\circ} \mathrm{C}$ and $\mathrm{pH}$ range of $2.6-5.5$. The $\mathrm{KM}$ and $\mathrm{Vmax}$ values were determined as $0.365 \mathrm{mM}$ and $0.093 \mathrm{U}$, respectively. Among the metals and sugars $\mathrm{Na}_{2} \mathrm{CO}_{3}$ and galactose showed strong inhibitory effect on the activity of enzyme. The availability of a new $\alpha$-galactosidase with different biochemical properties from $A$. lentulus by using TPP may be of interest for its various biotechnological applications.
\end{abstract}

\section{Key Words}

$\alpha$-galactosidase, bioseparation, three-phase partitioning (TPP), enzyme purification, enzyme characterization.

\section{öz}

\begin{abstract}
0 çlü-faz ayırma (TPP) tekniği $\alpha$-galaktozidazın Aspergillus lentulus'dan tek adımda kısmi saflaştırılması için ilk kez başarıyla kullanıldı. Yüksek aktivite ve saflaştırma katı elde etmek için enzimin ekstraksiyon etkinliğine amonyum sülfat konsantrasyonu, ekstrakt t-butanol oranı ve pH etkisi araştırıldı. Sistemin optimum saflaştırma parametreleri \%55(w/v) amonyum sülfat konsantrasyonu, 1:1 (v/v) ham ekstrakt t-butanol oranı ve pH 5.5 olarak belirlendi. Bu optimize TPP sistemi $\alpha$-galaktosidaz için 5.3 saflaştırma katı ile \%178 aktivite verimi oluşturdu. $\mathrm{pH} 6.5$ ve $50^{\circ} \mathrm{C}^{\prime}$ de maksimum aktivite gözlendi. a-Galaktozidaz $25-60^{\circ} \mathrm{C}$ sıcaklık aralığında ve pH 2.6-5.5 aralığında oldukça iyi bir kararlııı gösterdi. KM ve Vmax değerleri sırasıyla $0.365 \mathrm{mM}$ ve $0.093 \mathrm{U}$ olarak belirlendi. Metal iyonları ve şekerler arasında $\mathrm{Na}_{2} \mathrm{CO}_{3}$ ve galaktoz enzim aktivitesi üzerinde kuvvetli inhibitor etkisi gösterdi. TPP ile A. lentulus'dan farklı biyokimyasal özelliklere sahip yeni bir $\alpha$-galaktozidazın elde edilmesi onun çeşitli biyoteknolojik uygulamaları açısından ilgi çekici olacaktır.
\end{abstract}

\section{Anahtar Kelimeler}

$\alpha$-galaktozidaz, biyoayııım, üçlü-faz ayırma (TPP), enzim saflaştırma, enzim karakterizasyonu. 


\section{INTRODUCTION}

Thr hree-phase partitioning (TPP) is an elegant, modest and relatively new bioseparation strategy to separate and enrich various biomolecules including proteins, enzymes, enzyme inhibitors, oils and carbohydrates from natural sources such as plants, animals and microorganisms. TPP has several advantages in comparison to traditional extraction and separation techniques like; rapid, efficient, economical, green and scalable. It has generally been used as upstream and downstream separation process. There is no any exact mechanism for TPP, however it is known that a combination of different principles including kosmotropy, electrostatic forces, salting-out, isoionic and co-solvent precipitation, conformation tightening and protein hydration shifts are effective in separation of bioactive molecules [1-3]. According to biochemical properties (hydrophobicity, molecular weight, charge, isoelectric point) of a protein and also temperature and content of the separation medium (salt type and concentration, organic solvent type and concentration, $\mathrm{pH}$ and protein amount) proteins show different partitioning behaviour in TPP systems. TPP generally uses ammonium sulfate and t-butanol to precipitate proteins from aqueous solutions. After addition of a known amount of salt to aqueous crude protein extract t-butanol is added to the system to obtain three phases. The upper phase is containing nonpolar compounds like pigments and lipids. The middle phase is precipitated proteins. The lower phase is containing polar compounds like remaining proteins and saccharides. By optimization of TPP, the target proteins selectively partitioned to one phase while contaminating proteins to the other phase $[4,5]$.

TPP was used to purify several biomolecules such as oil $[6,7]$, polysaccharides [8,9], magniferin [10], enzyme inhibitors [11,12], anthocyanin [13]. TPP is also been widely used to separate, concentrate and purify several enzymes; peroxidase [14], serratiopeptidase [15], laccase [16], amylase [17], $\beta$-galactosidase [18], naringinase [19] etc.

$\alpha$-Galactosidases ( $\alpha$-D-galactoside galactohydrolase, EC 3.2.1.22) are important enzymes that broadly distributed in microorganisms, plants and animals. They catalyze the hydrolysis of $\alpha$-linked terminal non-reducing galactose residues from galactose oligosaccharides, galactomannans and galactolipids. $\alpha$-Galactosidases have find various industrial applications such as in su- gar industry to increase the yield of crystallized sugar, in feed industry as an animal feed additive to improve nutritional value, in pulp and paper industry to improve pulp bleaching and also in clinical applications such as for the treatment of Fabry's disease by enzyme replacement therapy and to convert B blood group to O blood group [20-22]. $\alpha$-Galactosidases have been purified from different microbial sources with a number of purification protocols including salting-out, ion-exchange, affinity chromatography etc [23-25]. These protocols have generally multiple steps, need large process times and also have high operation costs.

Because of potential and applicability of $\alpha$-galactosidases in diverse research areas it is necessary to find an alternative source for production. Aspergillus lentulus was found as a producer of $\alpha$-galactosidase and it contain high enzyme activity and could be use as an alternative enzyme source for $\alpha$-galactosidase production. So, in the present study, $A$. lentulus was used for concentration and purification of $\alpha$-galactosidase with TPP for the first time. It was aimed to extract, concentrate and purify $\alpha$-galactosidase from a crude extract of Aspergillus lentulus using a TPP protocol and also enzymatic characterization of the enzyme which make them advantageous in applications. It has been reported that physiological conditions influence partitioning of proteins in TPP [4]. The effect of different process parameters such as ammonium sulfate concentration, enzyme extract to t-butanol ratio and $\mathrm{pH}$ on partitioning yield of $\alpha$-galactosidase was optimized to obtain a good TPP system with high performance. The partitioned enzyme was also biochemically characterized. The influence of temperature and $\mathrm{pH}$ on activity and stability of partitioned enzyme was investigated. Kinetic constants $\left(\mathrm{K}_{\mathrm{M}}\right.$ and $V_{\text {max }}$ ) were determined. The selected metal ions and sugars were evaluated for activity of partitioned enzyme.

\section{MATERIALS and METHODS}

\section{Chemicals and Microorganism}

Ammonium sulfate and t-butanol were acquired from E. Merck (Germany). p-Nitrophenyl- $\alpha-D$ galactopyranoside (PNPG) and Coomassie Brilliant Blue R-250 were procured from Sigma (USA). Other chemicals were of an analytical grade.

The microorganism was isolated from sand of a hot spring (Eynal, Kütahya/Simav) in Turkey. The fungal strain which take part in Dr. A. Uzel's collection was coded 
and named as 2.2.45 and Aspergillus lentulus, respectively, and used as $\alpha$-galactosidase source.

\section{$\boldsymbol{\alpha}$-Galactosidase Production}

$\alpha$-Galactosidase was expressed using a thermotolerant fungi (Aspergillus lentulus) which was transferred to 1 $\mathrm{L}$ sterile production media. The production medium including $\mathrm{KH}_{2} \mathrm{PO}_{4}(7 \mathrm{~g}), \mathrm{K}_{2} \mathrm{HPO}_{4}(2 \mathrm{~g}), \mathrm{MgSO}_{4} .7 \mathrm{H}_{2} \mathrm{O}(2 \mathrm{~g})$, $\left(\mathrm{NH}_{4}\right)_{2} \mathrm{SO}_{4}(1 \mathrm{~g})$, yeast extract $(0.6 \mathrm{~g})$ and microcrystalline cellulose $(10 \mathrm{~g})$ in $1 \mathrm{~L}$ of distilled water was autoclaved to sterilize at $121^{\circ} \mathrm{C}$ for $20 \mathrm{~min}$. Then the medium was inoculated with small pieces of mycelia of the fungal strain and incubated at $45^{\circ} \mathrm{C}$ for 7 days with shaking (150 rpm). At the end of incubation period, the culture broth was centrifuged at $9000 \mathrm{rpm}$ for $30 \mathrm{~min}$ at $4^{\circ} \mathrm{C}$. After separating the cells, the supernatant was taken and analyzed. The activity and protein amounts were found as $0.013 \mathrm{U} / \mathrm{mL}$ and $0.005 \mathrm{mg} / \mathrm{mL}$, respectively. The proteins present in supernatant was precipitated with $80 \%(\mathrm{w} / \mathrm{v})$ ammonium sulfate. The mixture was left overnight at $4^{\circ} \mathrm{C}$ with stirring. The precipitated proteins was collected by centrifugation at $9000 \mathrm{rpm}$ for $30 \mathrm{~min}$ at $4^{\circ} \mathrm{C}$. After dissolving the pellet in sodium citrate buffer $(0.05 \mathrm{M}, \mathrm{pH} 6.0)$ it was dialyzed against the same buffer for overnight. The dialysate was named as "crude $\alpha$-galactosidase extract" and was analyzed for $\alpha$-galactosidase activity and protein amount $(0.38$ $\mathrm{U} / \mathrm{mL}, 3.71 \mathrm{mg} / \mathrm{mL}, 0.1 \mathrm{U} / \mathrm{mg}$ ). Afterwards it was stored at $-20^{\circ} \mathrm{C}$ for TPP experiments.

\section{Three-Phase Partitioning of $\boldsymbol{\alpha}$-Galactosidase}

A lentulus $\alpha$-galactosidase extract $(2 \mathrm{ml}$ containing $0.115 \mathrm{U}$ and $0.25 \mathrm{mg}$ protein) was mixed with ammonium sulfate $(55 \%, \mathrm{w} / \mathrm{v})$ at $25^{\circ} \mathrm{C}$ and thoroughly mixed on a vortex for $2 \mathrm{~min}$ for dissolving the salt. The $\mathrm{pH}$ of the medium was adjusted to $\mathrm{pH} 5.5$ with $\mathrm{HCl}$ followed by addidition of t-butanol 1:1 (v/v). The aqueous/organic system was stirred for $1 \mathrm{~min}$ and then left to stand for 1 $\mathrm{h}$ at $25^{\circ} \mathrm{C}$. After centrifugation at $4000 \mathrm{rpm}$ for $10 \mathrm{~min}$ at $4^{\circ} \mathrm{C}$ the separation of phases was observed. Afterwards the top t-butanol layer was removed and then the bottom aqueous layer and the middle phase were collected separately. The volume of phases were measured. The middle phase was dissolved in $0.5 \mathrm{ml}$ of $0.05 \mathrm{M}$ sodium citrate buffer ( $\mathrm{pH}$ 6.0). The bottom phase was dialysed for 3 hour against the same buffer. Both bottom and middle phases were then analyzed for enzyme activity and total protein concentration. The purification fold and recovery\% were calculated. The initially added enzyme activity was taken as $100 \%$.
The partitioning of enzymes in TPP systems was affected by several key parameters such as salt saturation, ratio of extract to organic solvent, and $\mathrm{pH}$. Therefore, to optimize the TPP system to get best recovery the experimental conditions for $\alpha$-galactosidase partitioning was described. Ammonium sulfate concentration was changed in the range of $20-70 \%, w / v$. Crude enzyme extract to t-butanol ratio was varied in the following range; 1:0.25-1:2 (v/v). $\mathrm{pH}$ was varied between 4.0 to 7.0. The optimized best conditions were used as standard purification protocol for Aspergillus lentulus $\alpha$-galactosidase. After optimization of TPP, the bottom phase which is containing high enzyme activity was collected and dialysed overnight against sodium citrate buffer (0.05 M, pH 6.0) to remove ammonium sulfate. $\alpha$-Galactosidase was concentrated with ultrafiltration (10 kDa). It was stored at $-20^{\circ} \mathrm{C}$ until use for determination of biochemical characteristic properties. A blank system without crude extract was used as control. All TPP experiments were performed in triplicate and the activity and protein determinations are also mean value of triplicate assay. The difference in the readings was less than $\pm 3 \%$.

\section{Repetition and Scalling-up of TPP}

In order to show the repeatability of TPP for $\alpha$-galactosidase recovery, the system was prepared and repeated for three times under optimum same conditions. For scale-up, TPP system was prepared as $x 1$ to x5 fold in volumes $(\mathrm{mL}) 15-75 \mathrm{ml}$ under optimum same conditions. After separation of the phases, both middle and bottom phase were analyzed for enzyme activity and protein amount. A blank system without crude extract was used as control. The purification fold and recovery\% were calculated. The initially added enzyme activity was taken as $100 \%$.

\section{Analytical Procedures \\ Enzyme assay}

The activity of $\alpha$-galactosidase was measured by PNPG [26]. The enzyme was appropriately diluted to $0.25 \mathrm{~mL}$ using sodium citrate buffer $(0.05 \mathrm{M}, \mathrm{pH}$ 6.0) (if necessary). $0.25 \mathrm{~mL}$ of PNPG solution and $0.5 \mathrm{~mL}$ of citrate buffer were added to the enzyme solution. The mixture was incubated at $37^{\circ} \mathrm{C}$ for $30 \mathrm{~min}$. The reaction was terminated by adding $3.5 \mathrm{~mL}$ of $0.2 \mathrm{M}$ sodium borate buffer ( $\mathrm{pH}$ 9.8). The amount of released $\mathrm{p}$-nitrophenol was determined spectrophotometrically at $400 \mathrm{~nm}$. One unit ( $1 \mathrm{U})$ of $\alpha$-galactosidase activity was defined as the amount of enzyme that liberated one $\mu \mathrm{mol}$ of 
p-nitrophenol from PNPG per min at $37^{\circ} \mathrm{C}$. The all given data for $\alpha$-galactosidase activity are mean values of triplicate assay.

\section{Estimation of protein}

Amount of protein was determined by Bradford method using Coomassie Blue G-250 dye as a reagent and bovine serum albumin was used as standard [27]. Specific activity is defined as the enzymatic unit per milligram of protein.

\section{Biochemical Characterization of Partitioned $\alpha$-Galactosidase}

\section{Effect of temperature on the enzyme activity and stability}

The temperature profile of $\alpha$-galactosidase was determined by performing the standard enzyme assay procedure using PNPG. The enzyme assays were assessed at different temperatures $\left(25\right.$ to $\left.80^{\circ} \mathrm{C}\right)$. The substrate solution was first preincubated in the respective temperature and then added to the enzyme solution to start the enzymatic reaction. The relative activities as percentage were expressed as the ratio of the enzyme activity obtained at a certain temperature to the maximum activity obtained at the given temperature range. Thermostability experiments were realized without using any additives. The enzyme was incubated at various temperatures ranging from 25 to $70^{\circ} \mathrm{C}$ for $30 \mathrm{~min}$. After that, the enzyme aliquots were withdrawn, brought to room temperature and the residual activity was measured at regular intervals of time under optimal assay conditions.

\section{Effect of pH on activity and stability}

Optimal $\mathrm{pH}$ of $\alpha$-galactosidase activity was determined in citrate/phosphate buffer $(0.05 \mathrm{M})$ of $\mathrm{pH}$ values ranging from $\mathrm{pH} 2.6$ to 7.5 . The enzyme in buffer of varying $\mathrm{pH}$ was analyzed for its activity and relative activity at each $\mathrm{pH}$ was calculated. The $\mathrm{pH}$ stability was searched by incubating the enzyme in above buffers with various $\mathrm{pHs}$ for $30 \mathrm{~min}$ at $4^{\circ} \mathrm{C}$ and then the remaining activity (\%) with respect to control was assayed.

\section{Determination of kinetic constants (KM and Vmax)}

Kinetic experiments were performed with PNPG. Its concentration was varied between 0.05-1.25 mM. Michaelis-Menten constant (KM) and the maximum velocity of reactions (Vmax) were calculated from Lineweaver-Burk plot.

\section{Effect of various effectors on activity}

The effect of different metal ions $\left(\mathrm{NaCl}, \mathrm{CaCl}_{2}, \mathrm{MgCl}_{2}\right.$, $\mathrm{LiCl}_{2}, \mathrm{CuSO}_{4^{\prime}}, \mathrm{MgSO}_{4^{\prime}} \quad \mathrm{Na}_{2} \mathrm{CO}_{3^{\prime}}, \mathrm{ZnSO}_{4^{\prime}} \quad \mathrm{MnCl}_{2^{\prime}}, \mathrm{LiSO}_{4^{\prime}}$ $\mathrm{MnSO}_{4}$ ) and sugars (galactose, sucrose, glucose, fructose, lactose, maltose, mellibiose and raffinose) in concentrations of $10 \mathrm{mM}$ on $\alpha$-galactosidase activity was searched. The enzyme was separately preincubated with above effectors for $30 \mathrm{~min}$ at room temperature and then the remaining activities were assayed and calculated. The enzymatic activity was assayed in the absence of effectors was considered as $100 \%$. The all given data for relative $\alpha$-galactosidase activity are mean values of triplicate assay.

\section{Inhibitory effect of galactose on $\boldsymbol{\alpha}$-galactosidase}

D-Galactose is known as an inhibitor of $\alpha$-galactosidases. Therefore, the inhibition effect of galactose on $\alpha$-galactosidase activity was studied by using PNPG. For the determination of the effect of galactose on enzyme activity, the enzyme assays were realized at constant substrate concentration and at various galactose concentrations. Enzyme activity without galactose was used as control as $100 \%$. Percent-activity graph was drawn and 150 value was calculated. With three different concentrations of galactose the enzyme activity was measured, the Lineweaver Burk graph was drawn and Ki constant values were also calculated.

\section{RESULTS and DISCUSSION \\ Partitioning of Aspergillus lentulus $\alpha$-Galactosidase}

Three phase partitioning (TPP) is proved to be an excellent procedure for enzyme extraction and purification. The purification fold and activity yield of an enzyme ontained from TPP were influenced both by the source of the enzyme and process parameters. Therefore, in the present work TPP was used as one-step purification protocol for $\alpha$-galactosidase from a new source; Aspergillus lentulus. Fungal strain A. lentulus has been proved to be producing highly active extracellular $\alpha$-galactosidase. The effect of ammonium sulfate saturation $(20-70 \%, w / v)$, enzyme extract to t-butanol ratio (1:0.25-1:2, v/v) and $\mathrm{pH}$ (4-7) on TPP of $\alpha$-galactosidase was investigated. The optimum partitioning conditions for efficient separation of the enzyme was determined. In all optimization experiments $\alpha$-galactosidase mainly partitioned and concentrated in aqueous bottom phase and gave high activity recovery and purification fold. 


\section{Effect of ammonium sulfate saturation}

Salts have key function in the process of TPP as they remarkably affect solubility of proteins. The solubility will vary according to the ionic strength of the solution. Hence, the effect of salt saturation on TPP of $\alpha$-galactosidase was studied. Ammonium sulfate is chosen as salt that the most widely used sulfate salt because of its low solubility. In comparison to other salts ammonium sulfate also has a high hydration capacity and affinity for water. In the case of sulfate ions which is a member of Hoffmeister series interact well with water, forming $\mathrm{H}$-bonds and dehydrate proteins and has high tendency to crowd proteins $[3,14,15]$. Critical concentration of salt is needed to be optimized to get the interested enzyme in the desired phase. This also bring out the extraction of the enzyme with minimum enterprice from contaminating substances from complex medium. In order to determine the best ammonium sulfate saturation, salt concentration was varied from
$20 \%$ to $70 \%(\mathrm{w} / \mathrm{v})$ The enzyme to t-butanol ratio was fixed to $1: 1(\mathrm{v} / \mathrm{v})$. by maintaining the ratio of crude extract to t-butanol ratio constant (1:1). The obtained results are shown in Figure 1. As can be seen from figure, maximum fold purification of 3.84-fold along with highest recovery (113\%) of $\alpha$-galactosidase activity in bottom phase was obtained with $55 \%$ (w/v) ammonium sulfate concentration. The enzyme was predominantly recovered at the bottom phase. Sometimes TPP may cause enchancing the enzyme activity due to increased flexibility in the enzyme molecule [3,4]. There are several reports that show the activation of enzymes after TPP such as; invertase [28], $\alpha$-galactosidase [29], pectinase [30], peroxidase [31] etc.

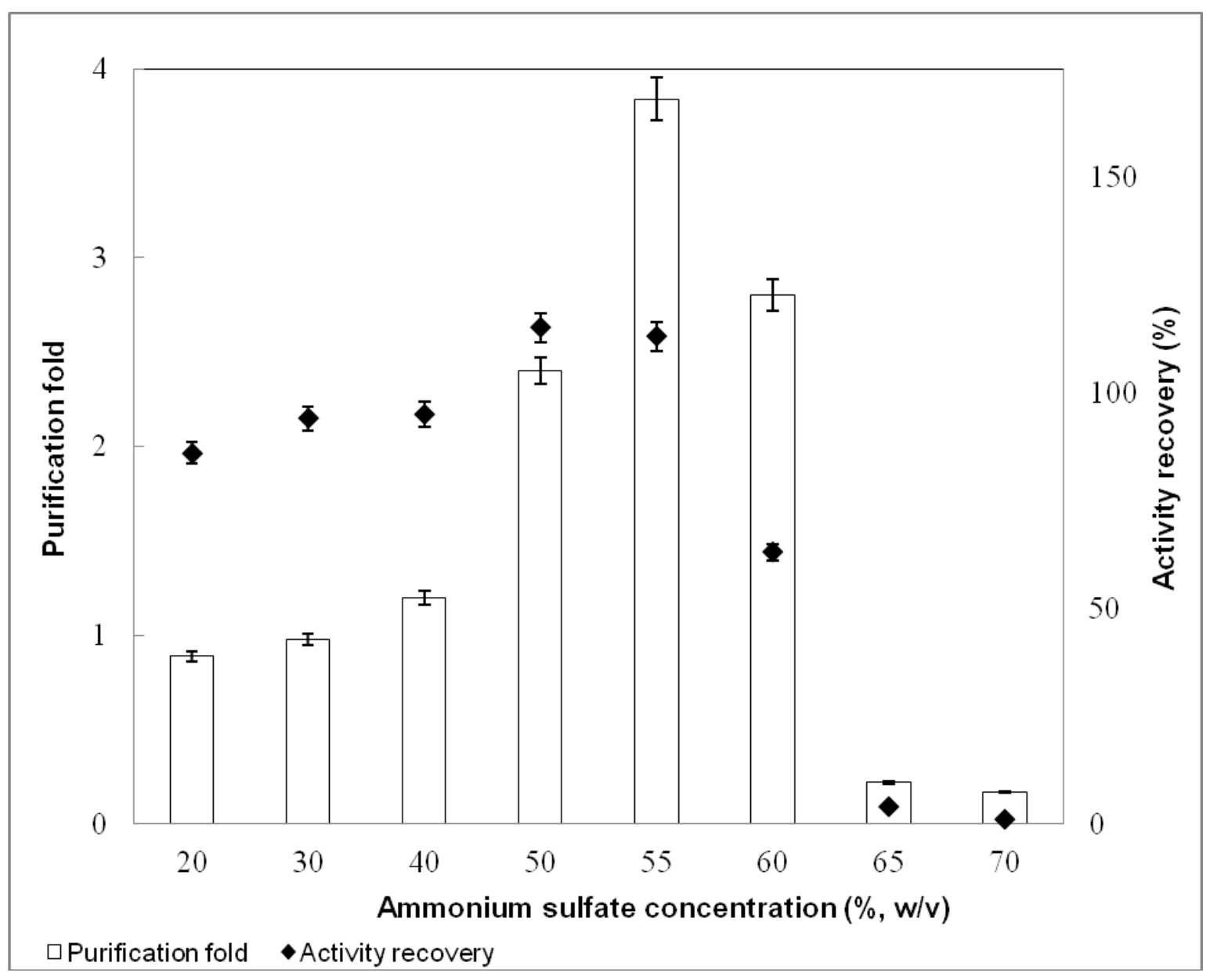

Figure 1. Effect of ammonium sulfate saturation on TPP of Aspergillus lentulus $\alpha$-galactosidase. The enzyme extract ( $2 \mathrm{ml}$ containing $0,115 \mathrm{U})$ was brought to different levels of saturation w.r.t. ammonium sulfate $(20 \%, 30 \%, 40 \%, 50 \%, 55 \%, 60 \%, 65 \%$, and $70 \%)$ and $\mathrm{t}$-butanol was added in the ratio of $1: 1(\mathrm{v} / \mathrm{v})$ with respect to the volumes of the aqueous extract. 


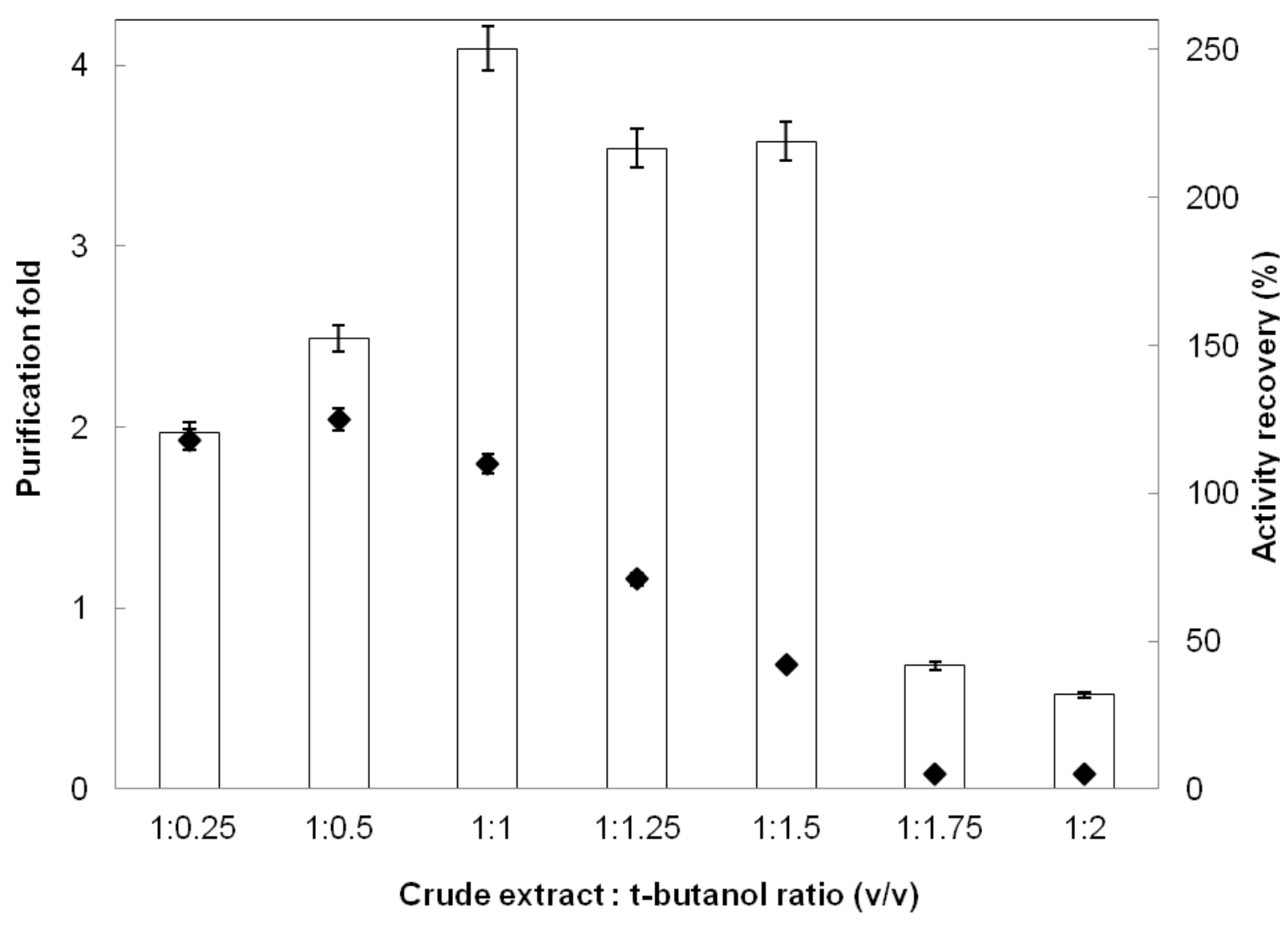

\section{$\square$ Purification fold $\bullet$ Activity recovery $(\%)$}

Figure 2. Effect of enzyme extract to t-butanol ratio on TPP of Aspergillus lentulus $\alpha$-galactosidase. Various amount of t-butanol was added to enzyme extract ( $2 \mathrm{ml}$ containing $0,115 \mathrm{U}$ and saturated with $55 \%$ ammonium sulfate) in the following volumetric ratios viz. $1: 0,25,1: 0.5,1: 1,1: 1,25,1: 1.5,1: 1,75$ and $1: 2$.

The purification fold and activity recovery values were increased significantly with an increase in concentration of salt from $20 \%$ to $50 \%$ (w/v). However, beyond $60 \%(\mathrm{w} / \mathrm{v})$ salt concentration both values were decreased. Especially above $60 \%(\mathrm{w} / \mathrm{v})$ concentration they have decreased sharply that indicate a decrease in the selectivity of extraction and also degree of purification. At lower concentrations, ammonium sulfate was unable to change the hydrophobic surface of $\alpha$-galactosidase. By increasing the salt concentration both the surface tension and interfacial tension of the TPP system increases. Therefore, higher tension values point out higher density and polarity differences between phases [31, 32]. Several researchers reported that, in TPP process salting out of a protein by sulfate is linked to kosmotropy, osmotic stressor, ionic-strength effects and the binding of sulfate to cationic sites of protein [3]. Hence $55 \%(\mathrm{w} / \mathrm{v})$ salt saturation is selected as optimal for further experiments.

\section{Effect of enzyme extract to t-butanol ratio}

Selection of organic solvent is very important that affect to the partitioning of an enzyme in TPP. Various C4 alcohols could be used as phase forming solvent in TPP systems. t-butanol is used as the solvent for partitioning of $\alpha$-galactosidase in TPP. t-butanol could make three-phase and efficiently remove small compounds. It has also been reported that t-butanol generally give the best partitioning results $[15,33]$. For the determination of best enzyme to t-butanol ratio, the salt saturation was fixed to $55 \%(\mathrm{w} / \mathrm{v})$ and enzyme extract to t-butanol ratio was varied from 1:0.25 to 1:2 (v/v). The maximum activity recovery and purification fold were obtained with 1:1 (v/v) ratio (Figure 2).

At lower t-butanol ratios (1:0.25 and 1:0.5, v/v) the recovered activity values were low. When t-butanol amount is lower it could not efficiently synergize with the salt [3]. If the t-butanol amount increases the concentration 


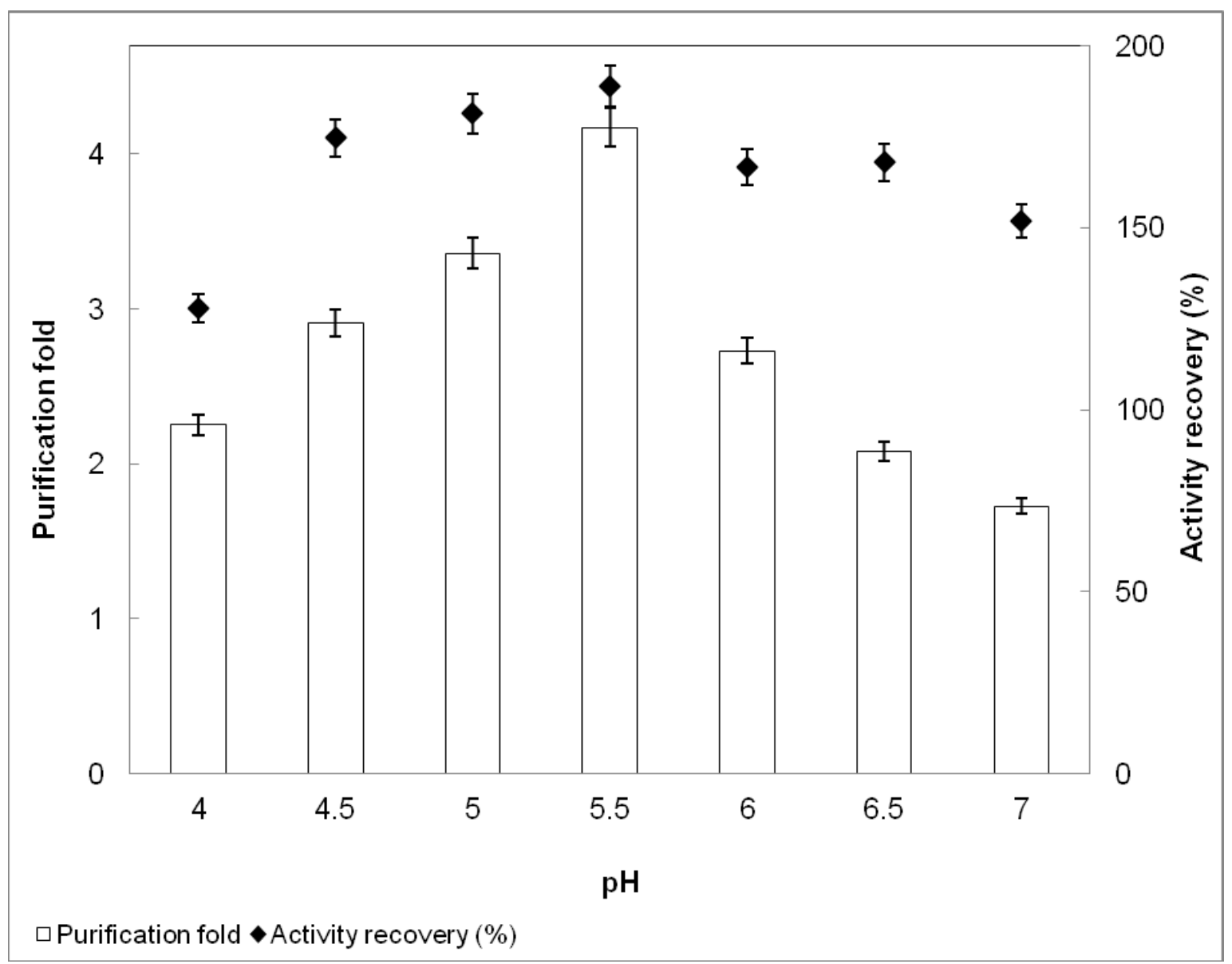

Figure 3. Influence of $\mathrm{pH}$ on on TPP of Aspergillus lentulus $\alpha$-galactosidase. Ammonium sulfate $(55 \%, w / v)$ was added to the enzyme extract of $\alpha$-galactosidase ( $2 \mathrm{ml}$ containing $0,115 \mathrm{U}$ ). The $\mathrm{pH}$ of the medium was adjusted to different $\mathrm{pH}$ values. This was followed by addition of t-butanol in a ratio of 1:1 (enzyme extract to t-butanol).

difference between two phases decreases. t-butanol could not easily permeate inside the folded protein molecules due to its size and branched structure. Hence, it does not cause denaturation [3-5, 34]. t-butanol also allows significant crowding effects at room temperature due to its kosmotropic properties which not only intensifies the partitioning process but also makes it convenient [3-5].

\section{Effect of $\mathrm{pH}$}

The $\mathrm{pH}$ of the medium is another key factor that affect the partitioning of an enzyme in TPP. Protein concentration by salting-out depends on the sulfate concentration and also $\mathrm{pH}$ dependent net charge of the proteins. In TPP, sulfate anion binds to the cationic sites in the protein and this is significantly influenced by $\mathrm{pH}$. Proteins tend to precipitate most readily at their isoelectric point. Due to electrostatic interactions between the phases and charged protein partitioning of biomolecu- les in TPP changes with $\mathrm{pH}[3,4]$. Therefore, the effect of $\mathrm{pH}$ on partitioning of $\alpha$-galactosidase should be searched. The effect of different $\mathrm{pH}$ (4-7) values on TPP of $\alpha$-galactosidase was studied at $55 \%(w / v)$ ammonium sulfate concentration with crude extract to t-butanol ratio of 1:1 (v/v). TPP behavior of $\alpha$-galactosidase is illustrated in Figure 3. It can be seen and stated from figure that, the enzyme was partitioned selectively to the aqueous phase at $\mathrm{pH} 5.5 .55 \%(\mathrm{w} / \mathrm{v})$ ammonium sulfate saturation with 1:1 (v/v) ratio of crude extract to t-butanol at pH 5.5 gave a maximum 4.2 fold purification and $189 \%$ activity recovery of the enzyme. The raised recovery at this $\mathrm{pH}$ could be a result of a better conformational stability of enzyme towards t-butanol at that $\mathrm{pH}$. The extraction efficiency was low between $\mathrm{pH}$ 4-5 and $\mathrm{pH}$ 6-7 as compared to $\mathrm{pH} 5.5$.

The net charge of a protein can be altered by facilitating change in $\mathrm{pH}$ and can directly influence the partitioning 
Table 1. Overall purification of $\alpha$-galactosidase from Aspergillus lentulus by three-phase partitioning. ${ }^{a}$

\begin{tabular}{|c|c|c|c|c|c|}
\hline Step & Total activity (Unit) & Total protein (mg) & $\begin{array}{c}\text { Specific activity } \\
\text { (Unit/mg) }\end{array}$ & Purification fold & $\begin{array}{c}\text { Activity yield } \\
(\%)\end{array}$ \\
\hline $\begin{array}{l}\text { Crude extract ( } 80 \% \text {, } \\
\text { w/v, ammonium } \\
\text { sulfate fraction) }\end{array}$ & 0.41 & 1.25 & 0.33 & 1.00 & 100 \\
\hline $\begin{array}{l}\text { TPP-interfacial } \\
\text { precipitate }\end{array}$ & 0.10 & 0.90 & 0.11 & 0.33 & 24 \\
\hline TPP-aqueous phase & 0.73 & 0.42 & 1.74 & 5.3 & 178 \\
\hline
\end{tabular}

performance of biomolecules in the system [35]. In TPP, it is sighted that with an increase in $\mathrm{pH}$ beyond the $\mathrm{pl}$ infers net negative charge on protein and partitioned it to aqueous phase. So, $\alpha$-galactosidase has tendency to participitate to the bottom phase that is releated to its structure. Generally TPP systems suddenly change around the isoelectric point of proteins and it is linked to the $\mathrm{pH}$ of the system $[3,4]$.

\section{Evaluation of $\alpha$-galactosidase partitioning}

The partitioning and concentration of Aspergillus lentulus $\alpha$-galactosidase with one step TPP is summarized in Table 1. The enzyme is concentrated in bottom phase of the system depending to its structure. $\alpha$-Galactosidase was efficiently partitioned and concentrated with high activity recovery (178\%) and degree of purification (5.3-fold) under best conditions (55\% (w/v) ammonium sulfate concentration, 1:1 enzyme extract to t-butanol ratio, $\mathrm{pH}$ 5.5).

There are several reports that have been used for purification of various biomoecules like proteins, enzymes, oils, saccharides etc $[6,8,11,15,19]$. TPP based separations have several superiorities in comparison to conventional techniques; selective partition and concentration of desired enzyme to one phase, inexpensive, recycle of t-butanol, less steps, at room temperature $[5,30]$. Beside of this, it is possible to concentrate proteins from crude extracts with good activity yields and fold purification than traditional concentration methods. TPP is also as a concentrating and dewatering protocol that several enzymes could increase their catalytic activities in system. Sometimes this protocol may lead to contemporaneous activation of enzyme. The obser- ved activity yield may be due to increased flexibility in enzyme molecule [36]. The results showed that, TPP is a useful and efficient technique for concentration and purification of $\alpha$-galactosidase from $A$. lentulus under optimized conditions.

\section{Repetition and scale-up of TPP of $\alpha$-galactosidase} Under optimized partitioning conditions the TPP system was established separately for three times. The results are shown in Figure $4 a$. The activity recovery values were $162 \%, 178 \%$ and $165 \%$, respectively. For scallingup, five TPP system under optimized conditions was prepared in different volumes ( $x 1$ to $\times 5$ ) as 15 to $75 \mathrm{ml}$. The activity recovery values were found as $161 \%, 171 \%$, $165 \%, 163 \%$ and $178 \%$, respectively (Figure $4 \mathrm{~b}$ ). The repeatability and scalling-up of a TPP system is considerable for industrial and economical purposes. The results showed that TPP system for $\alpha$-galactosidase could be operated by giving similar findings. The bottom phase of TPP obtained from scalling-up was dialysed and used for further biochemical characterization studies.

\section{Biochemical Properties of Partitioned $\alpha$-Galactosidase}

Concentration and partial purification of $\alpha$-galactosidase from A. lentulus has been carried out using TPP. Biochemical characterization of partitioned enzyme which make it a good alternative for useability in several industries such as food, feed, paper, sugar also studied. The features of $\alpha$-galactosidase concerning remaining activity, the effect of temperature, $\mathrm{pH}$, substrate concentration and different effectors on the activity of enzyme and the effect of temperature and $\mathrm{pH}$ on the stability of enzyme were also investigated. The results 


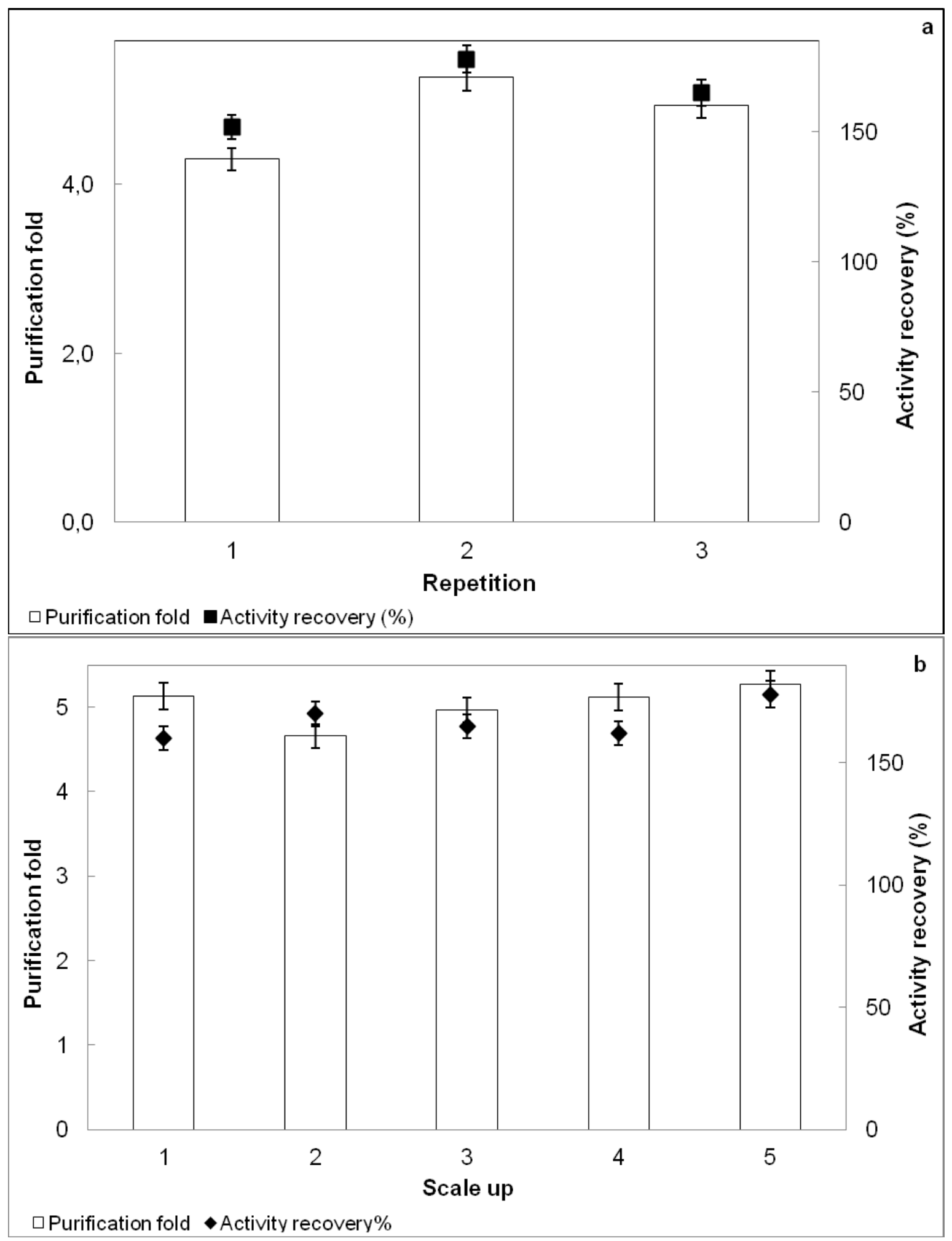

Figure 4. Repetition (a) and scalling-up (b) of TPP for Aspergillus lentulus $\alpha$-galactosidase recovery. 


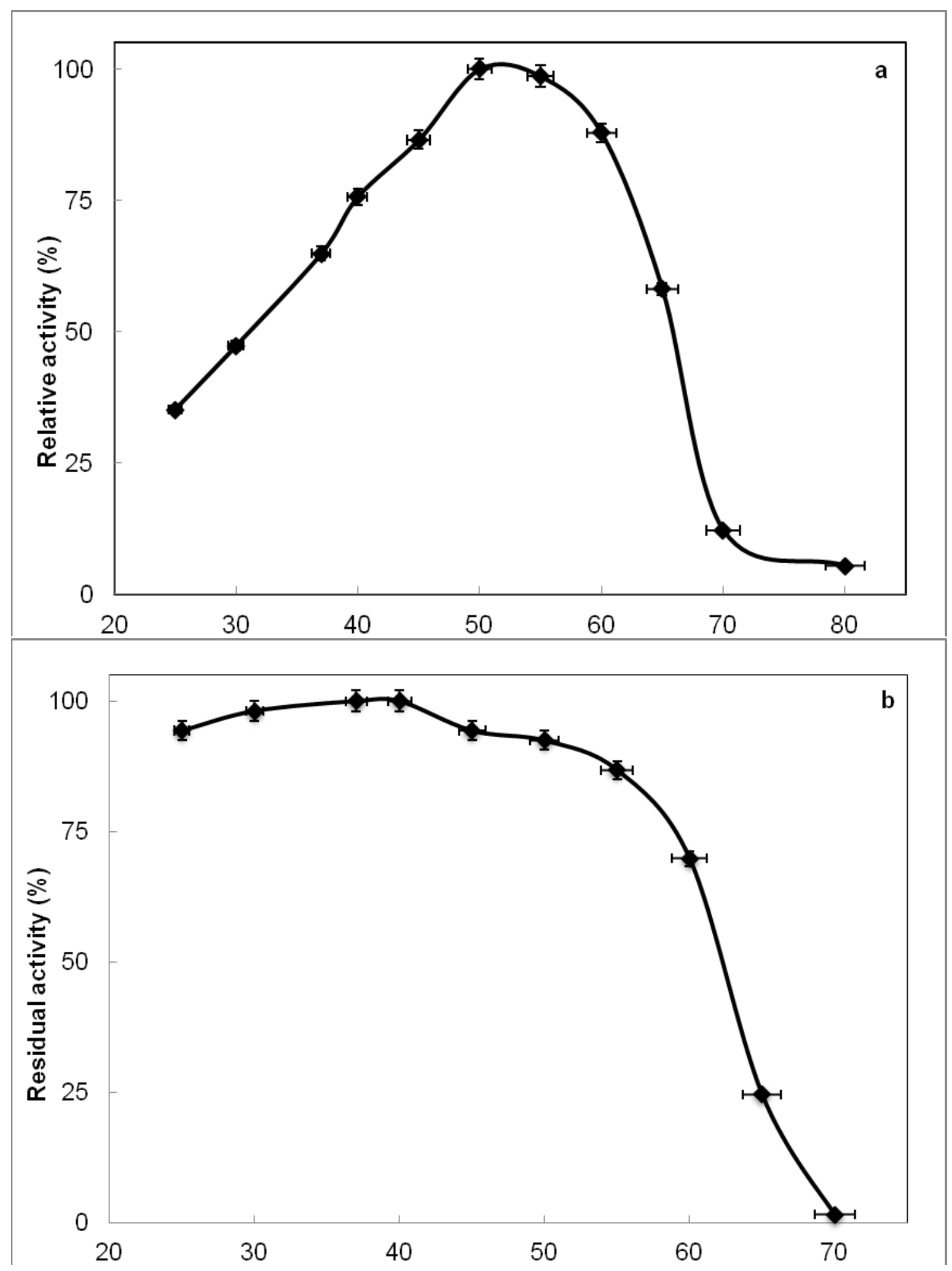

Figure 5. Influence of temperature on the activity (a) and stability (b) of Aspergillus lentulus $\alpha$-galactosidase. 
were given in proper sections by regarding figures and tables and evaluated. All characterization experiments were performed in triplicates and the activity determinations are mean value of triplicate assay. The difference in readings was less than $\pm 3 \%$.

\section{Influence of temperature on activity and stability of partitioned $\alpha$-galactosidase}

Three dimensional structure of enzymes must be protected for its activity. Temperature is one important parameter that affect the enzymeatic activity. The effect of temperature on catalytic activity of $\alpha$-galactosidase was determined in the temperature range of $25-80^{\circ} \mathrm{C}$. The maximum activity was observed at $50^{\circ} \mathrm{C}$ and at temperatures higher than $60^{\circ} \mathrm{C}$ the enzyme lost its activity quickly(Figure 5a). High temperatures could break the ionic and hydrogen bonds between the aminoacids of the enzyme. This cause denaturation and inactivation of enzyme. Thermostability of $\alpha$-galactosidase is also studied by measuring the residual activity of the enzyme after incubation at various temperatures (25$70^{\circ} \mathrm{C}$ ) for $30 \mathrm{~min}$. The thermostability of $\alpha$-galactosidase is very good in the temperature range of $25-60^{\circ} \mathrm{C}$ and it retains more than $50 \%$ of its initial activity at these temperatures (Figure $5 \mathrm{~b}$ ). About $70 \%$ of its original activity was maintained at the end of incubation at $60^{\circ} \mathrm{C}$ for 30 $\mathrm{min}$. This high temperatures are favorable for its industrial application because of lower risk of contamination.

There are several profiles that show the effect of temperature on $\alpha$-galactosidase activity and stability which is depending to enzyme source. For instance, the optimum activity for $F$. oxysporum $\alpha$-galactosidase was found at $35^{\circ} \mathrm{C}$. After $1 \mathrm{~h}$ incubation at $40^{\circ} \mathrm{C}$ all the enzyme activity has been retained [23]. Optimum temperature of $\mathrm{P}$. djamor $\alpha$-galactosidase was reported as $53.5^{\circ} \mathrm{C}$ and the enzyme was preserved $68 \%$ of its initial activity after incubation at $50^{\circ} \mathrm{C}$ for $1 \mathrm{~h} \mathrm{[24].} \mathrm{Zhou} \mathrm{et} \mathrm{al.}$ [23] have informed the optimal activity of recombinant $\alpha$-galactosidases from Mesorhizobium and Streptomyces were $45^{\circ} \mathrm{C}$ and $35^{\circ} \mathrm{C}$, respectively. The first enzyme was also found as very stable between $35-50^{\circ} \mathrm{C}$. $\alpha$-Galactosidase from $\mathrm{T}$. leycettamus had a temperature optimum of $70^{\circ} \mathrm{C}$ and showed good thermostability at $65^{\circ} \mathrm{C}$ after $1 \mathrm{~h}$ incubation and retained more than $60 \%$ of its initial activity [37]. P. purpurogenum $\alpha$-galactosidase have an optimum at $50^{\circ} \mathrm{C}$. It is also compared with other fungal $\alpha$-galactosidases [20]. As most the fungal enzymes have high temperature optimums $\left(50-75^{\circ} \mathrm{C}\right)$ and thermostability $\left(40-70^{\circ} \mathrm{C}\right)$ for various times $[20,37]$.

\section{Influence of pH on activity and stability of partitioned $\alpha$-galactosidase}

Biochemical reactions taking place in vivo in an aqueous environment, $\mathrm{pH}$ affects the activity of the enzyme due to the charge status. Optimum $\mathrm{pH}$ of $A$. lentulus $\alpha$-galactosidase was found as $\mathrm{pH} 6.5$ (Figure 6a). The enzyme was found to retain more than $50 \%$ of its activity at a broad $\mathrm{pH}$ range of 3.5-7.0. The results revealed that, $\alpha$-galactosidase is more active in the neutral range as compared to the acidic range. $\mathrm{pH}$ stability of an enzyme is affected by many factors such as buffer type, its concentration, ionic strength and also incubation time. As shown in Figure 6b, $\alpha$-galactosidase is fairly stable between $\mathrm{pH}$ range of 2.6-6.5 and remains initial activity more over $50 \%$.

The results compare well with the previous results obtained by otherl authors using different $\alpha$-galactosidases. $\mathrm{Hu}$ et al. [24], indicated that the optimum $\mathrm{pH}$ of P. djamor $\alpha$-galactosidase is $\mathrm{pH} 5.0$ and the enzyme is quite stable over a broad range of $\mathrm{pH} 3-10$. It is known that, several fungal $\alpha$-galactosidases are active in acidic and/ or neutral $\mathrm{pH}$ range. Morales-Quintana have showed an optimal pH for P.purpurogenum as $\mathrm{pH}$ 5.0. The various $\alpha$-galactosidases with different $\mathrm{pH}$ optimum [24] and $\mathrm{pH}$ stability [25] could be available. For instance, recombinant $\alpha$-galactosidase from Mesorhizobium exhibited more than $70 \%$ of its activity within $\mathrm{pH}$ range of 7-9 and from Streptomyces exhibited more than $40 \%$ of its activity within pHrange of 8 to 10.5 [25].

\section{Kinetic constants of partitioned $\alpha$-galactosidase}

The variation of enzymatic activity with the PNPG concentration in the range from 0.05-1.25 $\mathrm{mM}$ was investigated at $37^{\circ} \mathrm{C}$ to determine the kinetic constants. A Lineweaver-Burk plot of the data indicates that the enzyme follows simple Michaelis-Menten kinetics. KM and Vmax values were estimated and calculated from Lineweaver-Burk graph as $0.365 \mathrm{mM}$ and $0.093 \mathrm{U}$, respectively (data not shown). The KM value of $A$. lentulus $\alpha$-galactosidase is in agreement with those presented in literature. KM from other fungal $\alpha$-galactosidases ranging from 0.11 to $11 \mathrm{mM}$. This indicate that the enzyme has high affinity towards the PNPG $[20,22,23]$.

\section{Influence of various effectors on partitioned $\boldsymbol{\alpha}$-galactosidase activity}

The effect of various metal ions and sugars on the activity of $\alpha$-galactosidase was searched. The results are summarized for metal ions and for sugars in Table 2 and 


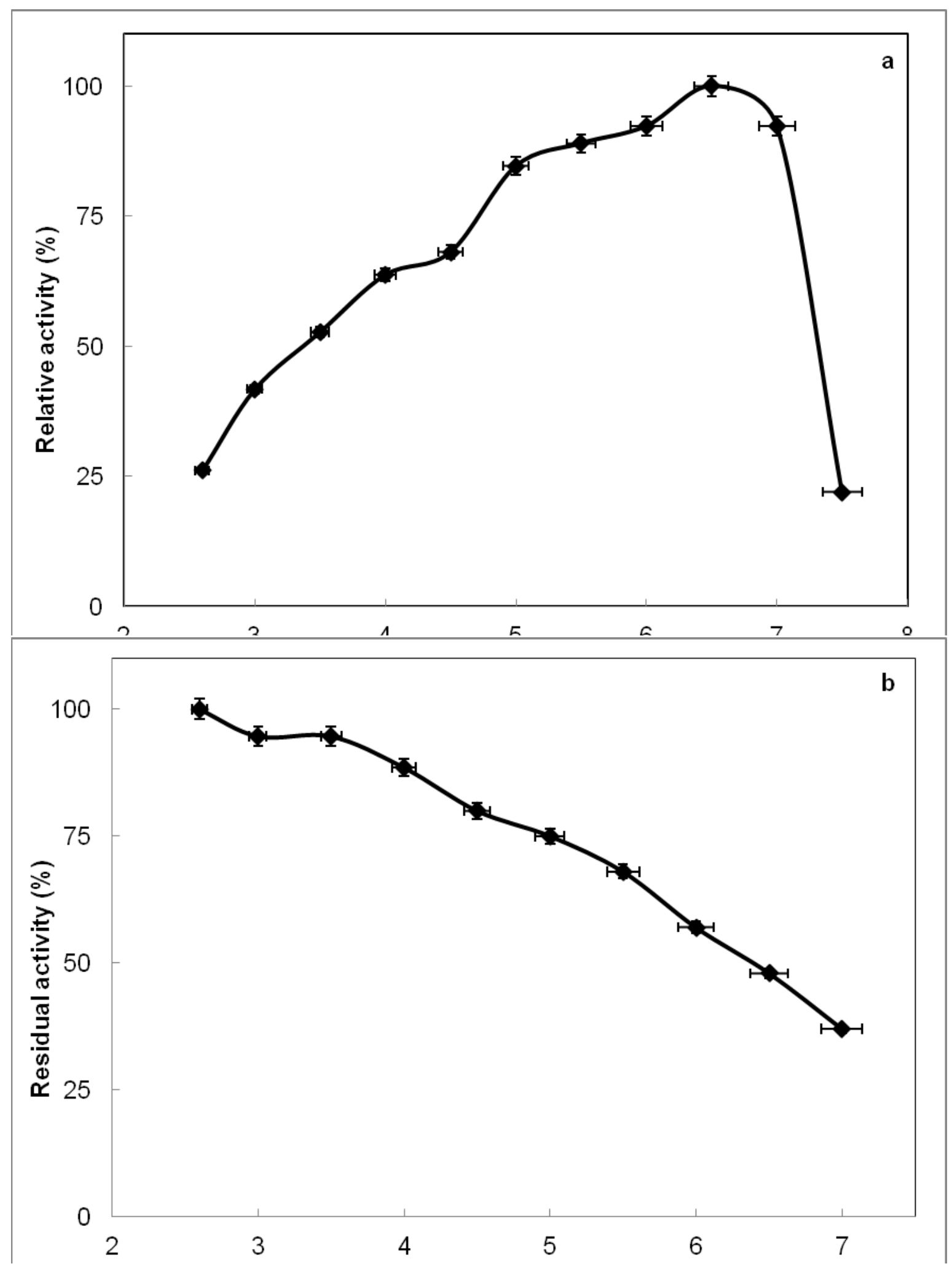

Figure 6. IInfluence of $\mathrm{pH}$ on the activity (a) and stability (b) of Aspergillus lentulus $\alpha$-galactosidase. 
Table 2. Effects of various ions on the activity of Aspergillus lentulus a-galactosidase a

\begin{tabular}{cc}
\hline Metal ions & Relative activity (\%) \\
\hline Control & 100 \\
\hline $\mathrm{NaCl}$ & 82 \\
\hline $\mathrm{CaCl}_{2}$ & 105 \\
\hline $\mathrm{MgCl}_{2}$ & 118 \\
\hline $\mathrm{LiCl}^{2}$ & 100 \\
\hline $\mathrm{CuSO}_{4}$ & 145 \\
\hline $\mathrm{MgSO}_{4}$ & 107 \\
\hline $\mathrm{Na}_{2} \mathrm{CO}_{3}$ & 7 \\
\hline $\mathrm{ZnSO}_{4}$ & 130 \\
\hline $\mathrm{MnCl}_{2}$ & 118 \\
\hline $\mathrm{LiSO}_{4}$ & 95 \\
\hline $\mathrm{MnSO}_{4}$ & 107 \\
\hline
\end{tabular}

a After preincubation of Aspergillus lentulus $\alpha$-galactosidase with different compounds at $10 \mathrm{mM}$ concentration of them at $25^{\circ} \mathrm{C}$ for 30 min the remaining enzyme activity was measured with standard activity assay procedure. Activity without added compounds taken as $100 \%$ activity. Data present the means of three determinations.

Table 3, respectively. As it could be observed from the tables, all these effectors had different effects on the activity of $\alpha$-galactosidase. As is seen from the Table 2, among metal ions $\mathrm{Na}_{2} \mathrm{CO}_{3}$ showed a strong inhibitory effect and had nearly $7 \%$ of inhibition. $\mathrm{CuSO}_{4}$ and $\mathrm{ZnSO}_{4}$ strongly activated the enzyme and had $145 \%$ and $130 \%$ activatory effect, respectively. $\mathrm{CaCl}_{2}, \mathrm{MgCl}_{2}, \mathrm{MgSO}_{4}, \mathrm{MnCl}_{2}$ and $\mathrm{MnSO}_{4}$ have slightly activated the enzyme. Beside of this, $\mathrm{NaCl}$ and $\mathrm{LiSO}_{4}$ have slightly inhibited the enzyme.

For sugars tested, all sugars have an inhibitory effect with different levels (Table 3). However, galactose strongly inhibited the enzymatic activity. Galactose is known as a common inhibitor of $\alpha$-galactosidases.
There are various results in literature that $\alpha$-galactosidases were influenced with different metals at various degrees. Maruta et al. [23] have reported that several metal ions $\left(\mathrm{Ag}^{+}, \mathrm{Hg}^{+2}\right.$ and $\left.\mathrm{Zn}^{+2}\right)$ inhibited the F. oxysporum $\alpha$-galactosidase completely. The enzyme was moderately inhibited with $\mathrm{Co}+2$ and $\mathrm{Cu}+2$. Recombinant $\mathrm{T}$. leycettanus $\alpha$-galactosidase was found very resistant to different metal ions and chemicals [22]. The enzymatic activity of $\alpha$-galactosidase from $\mathrm{Me}$ sorhizobium was enhanced by $\mathrm{ZnSO}_{4}$ and $\mathrm{Pb}\left(\mathrm{CH}_{3} \mathrm{COO}\right)_{2}$ at 0.5-30 mM [25]. Hu et al. [24] have indicated that, $\alpha$-galactosidase from $P$ djamor was significantly enhanced in the presence of $\mathrm{Zn}^{+2}, \mathrm{Fe}^{+2}, \mathrm{Mn}^{+2}$ and $\mathrm{Ca}^{+2}$. $\mathrm{Pb}^{+2}$ and $\mathrm{Mg}^{+2}$ showed an inhibitory effect on enzyme

Table 3. Effects of various carbohydrates on the activity of Aspergillus lentulus $\alpha$-galactosidase ${ }^{\text {a }}$

\begin{tabular}{cc}
\hline Carbohydrates & Relative activity(\%) \\
\hline Control & 100 \\
\hline Mellibiose & 42 \\
\hline Maltose & 89 \\
\hline Lactose & 83 \\
\hline Raffinose & 76 \\
\hline Glucose & 83 \\
\hline Galactose & 2 \\
\hline Sucrose & 93 \\
\hline Fructose & 91
\end{tabular}

a After preincubation of Aspergillus lentulus $\alpha$-galactosidase with different carbohydrates at $10 \mathrm{mM}$ concentration of them at $25^{\circ} \mathrm{C}$ for 30 min the remaining enzyme activity was measured with standard activity assay procedure. Activity without added carbohydrates taken as $100 \%$ activity. Data present the means of three determinations. 

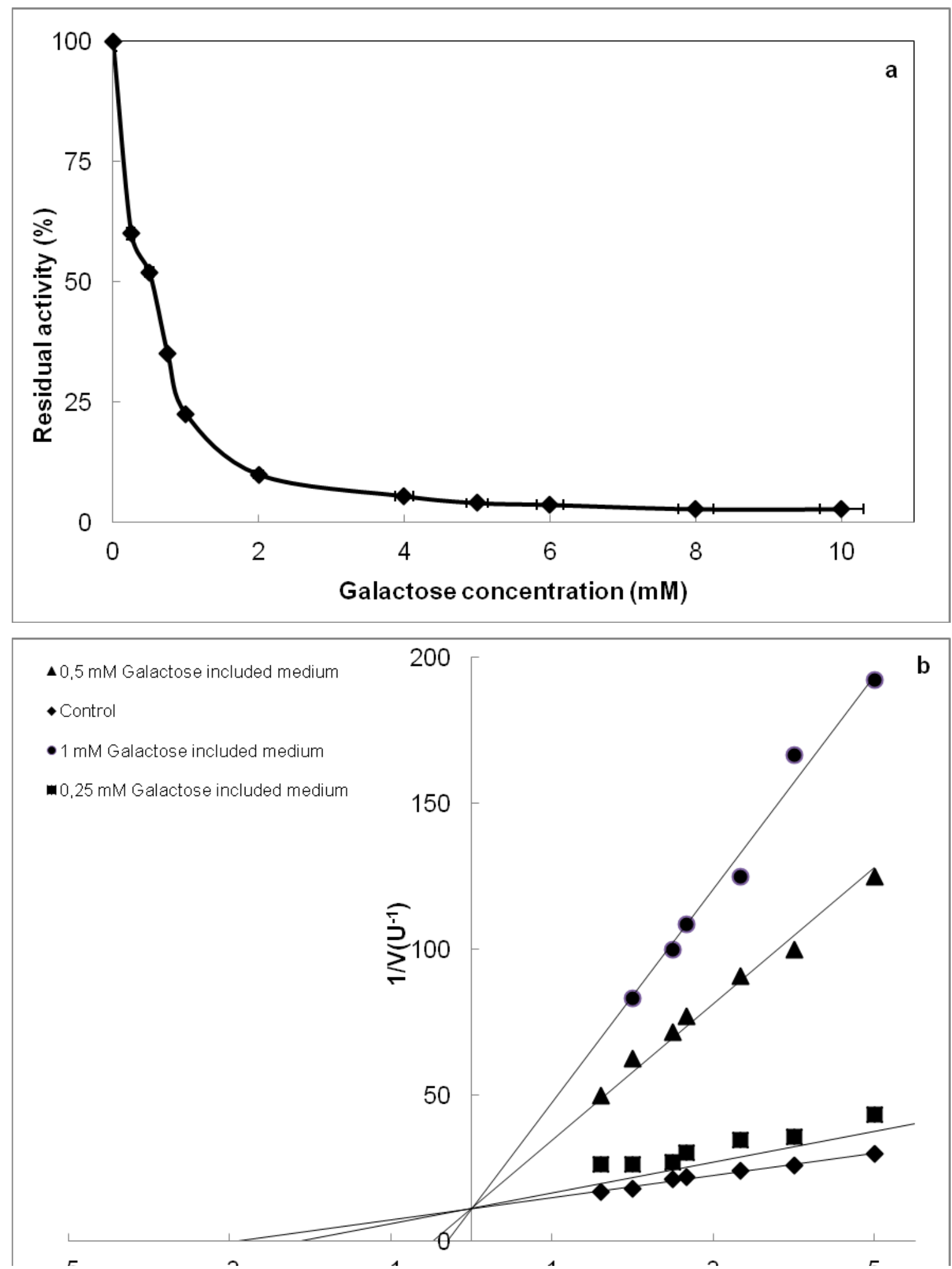

Figure 7. Effect of galactose concentration on the activity (a) of Aspergillus lentulus $\alpha$-galactosidase and Lineweaver -Burk plot (b). 
activity. The effects of different sugars on $\mathrm{P}$ djamor $\alpha$-galactosidase activity was also searched. They have found that, the enzyme was severely inhibited with melibiose and galactose [24].

\section{Inhibitory effect and kinetics of galactose on partitioned $\alpha$-galactosidase}

$D$-Galactose is also an inhibitor of $\alpha$-galactosidases from microbial sources $[20,24,38]$. The effect of various concentrations $(0.25-10 \mathrm{mM})$ of galactose on $\alpha$-galactosidase activity was assayed.

The reciprocals of the activity recovery (\%) as a function of the initial galactose concentration is reported in Figure 7a. IC50 value was calculated from graph as $0.42 \mathrm{mM}$. By using $0.25,0.5$ and $1.0 \mathrm{mM}$ of galactose concentrations the L. Burk plot was drawn (Figure 7b). KI values were calculated from the graph as 0.322, 0.475 and 2.102 $\mathrm{mM}$ for $0.25,0.5$ and $1.0 \mathrm{mM}$ galactose concentrations, respectively. Our results showed that, data were fitted to the model of competitive inhibition by galactose. Galactose, one of the products of the catalytic action of $\alpha$-galactosidases on $\alpha$-D-galactosides, is reported as being a competitive inhibitor of $\alpha$-galactosidases from different sources [39-41].

\section{Conclusion}

Aspergillus lentulus was found as a good source for $\alpha$-galactosidase. Fungal $\alpha$-galactosidases have several advantages such as their extracellular localization, acidic or neutral $\mathrm{pH}$ optima and broad stability profiles. Because of this, it is very easy to produce them, have better safety and very suitable for its biotechnological applications. $\alpha$-Galactosidase was concentrated and simultaneously purified from A. lentulus with 5.3 purification fold and $178 \%$ activity recovery by TPP under optimal partitioning conditions (55\% (w/v) ammonium sulfate concentration with $1: 1(\mathrm{v} / \mathrm{v})$ ratio of crude extract to t-butanol at $\mathrm{pH}$ 5.5). TPP as an emerging elegant bioseparation technique has been widely used for the recovery and purification of various enzymes fron newer sources that have many advantages in comparison to traditional separation and purification techniques like fast, simple, scale-applicable and economic. The number of unit operation involved in the classical chromatographic protocols is also reduced. $\alpha$-Galactosidase from $A$. lentulus was also characterized. Biochemical characterization of the enzyme revealed its superior properties like stability, over a broad temperature and $\mathrm{pH}$ range, strong resistance to metal ions and sugars.
$\alpha$-Galactosidase obtained from TPP with these good characteristics could be applied safetly especially in food, feed, sugar, pulp and paper industries.

\section{Acknowledgement}

This work has been supported by The Scientific and Technological Research Council of Turkey (TUBITAK) 2209A, 2015.

\section{References}

1. J.K., Yan, Y.Y., Wang, W.Y., Ma, H., Qiu, Z.B., Wang, J.Y. Wu, Three-phase partitioning as an elegant and versatile platform applied to non-chromatographic bioseparation processes. Crit. Rev. Food Sci. Nutr., 13 (2017) 1-16.

2. C.R., Rachana, J.V. Lyju, Three-phase partitioning-A novel protein purification method. Int. J. Chem Tech Res., 6 (2014) 3467-3472.

3. C., Dennison, R. Lovrien,Three-phase partitioning: Concentration and purification of proteins. Protein Exp. Purif., 11(1997) 149-161.

4. C., Dennison, R.N. Pike, Protein fractionation by three-phase partititioning in aqueous/t-butanol mixtures. Biotechnol. Bioeng., 33 (1989) 221-228.

5. R.E., Lovrein, C., Goldensoph, P., Anderson, B. Odegard,Threephase partitioning (TPP) via butanol: Enzyme separation from crudes, in: R. Burgess (Ed.), Protein purification: Micro to macro, A.R., Liss, Inc., New York, 1987, pp.131-148.

6. R., Dutta, U., Sarkar, A. Mukherjee,Process optimization for the extraction of oil from Crotalaria juncea using three phase partitioning. Ind. Crops Prod., 71 (2015) 89-96.

7. D.C., Panadare, V.K. Rathod, Three phase partitioning for extraction of oil: A review, Trends Food Sci. Technol., 68 (2017) 145-151.

8. J.K., Yan, Y.Y., Wang, W.Y., Qui, Z.B., M., H. Wang, Ultrasound synergized with three-phase partitioning for extraction and separation of Corbicula fluminea polysaccharides and possible relevant mechanisms. Ultrasonics-Sonochemistry, 40 (2018) 128-134.

9. Z.J., Tan, C.Y., Wang, Y.J., Yi, H.Y., Wang, W.L., Zhou, S.Y., Tan, F.F. Li, Three-phase partitioning for simultaneous purification of aloe polysaccharide and protein using a single-step extraction. Process Biochem., 50 (2015) 482-486.

10. V.M., Kulkarni, V.K. Rathod, Extraction of magniferin from Magnifera indica leaves using three phase partitioning coupled with ultrasound. Ind. Crops Prod., 52 (2014) 292297.

11. L., Saxena, B.K, Iyer, L. Ananthanarayan, Three phase partitioning as a novel method for purification of ragi(Eleusine coracana) bifunctionalamylase/protease inhibitor. Process Biochem., 42 (2007) 491-495.

12. I., Roy, M.N. Gupta, Three-phase affinity partitioning of proteins. Anal. Biochem. 300 (2002) 11-14.

13. C., Jampani, K.S.M.S. Raghavarao, Differential partitioning for purification of anthocyanins from Brassica oleracea L. Sep. Purif. Technol. 151 (2015) 57-65.

14. D., Panadare, V.K. Rathod, Extraction of peroxidase from bitter gourd (Momordica charantia) by three phase partitioning with dimethyl carbonate (DMC) as organic phase. Process Biochem. 61 (2017) 195-201. 
15. S.V., Pakhale, S.S. Bhagwat, Purification of serratiopeptidase from Serratio macescens NRRL B 23112 using ultrasound assisted three phase partitioning. UltrasonicsSonochemistry. 31 (2016) 532-538.

16. P.D., Patil, G.D. Yadav, Application of microwave assisted three phase partitioning method for purification of laccase from Trametes hirsuta. Process Biochem., 65 (2018) 220-227.

17. S.T., Sagu, E.J., Nso, T., Homann, C., Kapseu, H.M. Rawel, Extraction and purification of beta-amylase from stems of Abrus precatorius by three phase partitioning. Food Chem. 183 (2015) 144-153.

18. H.S., Choonia, S.S. Lele, Three-phase partitioning of $\beta$-galactosidase produced by an indigous Lactobacillus acidophilus isolate. Sep. Purif. Technol. 110 (2013) 144-150.

19. M., Shanmugaprakash, V., Vinothkumar, J., Ragupathy, D.A. Reddy, Biochemical characterization of three phase partitioned naringinase from Aspergillus brasiliensis MTCC 1344. Int. J. Biol.Macromol. 80 (2015) 418-423.

20. L., Morales-Quintana, C., Faundez, R., Herrera, V., Zavaleta, M.C., Ravanal, J., Eyzaguirre, M.A., Moya-Leon, Biochemical and structural characterization of Penicillium purpurogenum $\alpha$-D-galactosidase: Binding of galactose to an alternative pocket may explain enzyme inhibition. Carbohyd. Res., 448 (2017) 57-66.

21. V.V., Daitx, J., Mezzalira, V., da Costa Moraes, A.C., Breirer, J., Ce, J.C. Coelho, Comparing the alpha-galactosidase A biochemical properties from healthy individuals and Fabry disease patients. Clin. Chim. Acta, 445 (2015) 60-64.

22. C., Wang, H., Wang, R., Ma, P., Shi, C., Niu, H., Luo, P., Yang, B. Yao, Biochemical characterization of a novel thermophilic $\alpha$-galactosidase from Talaromyces leycettanus JCM12802 with significant transglycosylation activity. J. Biosci. Bioeng., 121 (2016) 7-12.

23. A., Maruta, M., Yamane, M., Matsubara, S., Suzuki, M., Nakazawa, M., Ueda, T. Sakamoto, A novel $\alpha$-galactosidase from Fusarium oxysporum and its application in determining the structure of the gum arabic side chain. Enzyme Microb. Technol., 103 (2017) 25-33.

24. Y., Hu, G., Tian, L., Zhao, H., Wang, T.B. Ng, A proteaseresistant $\alpha$-galactosidase from Pleurotus djamor with broad $\mathrm{pH}$-stability and good hydrolytic activity toward raffinose family oligosaccharides. Int. J. Biol.Macromol. 94 (2017) 122-130.

25. J., Zhou, Q., Lu, R., Zhang, Y., Wang, Q., Wu, J. Li,, X., Tang, B., Xu, J., Ding, Z. Huang, Characterization of two glycoside hydrolyse family $36-\alpha$-galactosidases: Novel transglycosylation activity, lead-zinc tolerance, alkaline and multiple $\mathrm{pH}$ optima and low-temperature activity. Food Chem. 194 (2016) 156-166.

26. S. Önal, A. Telefoncu, Preparation and properties of $\alpha$-galactosidase chemically attached to the activated chitin. Art. Cells Blood Subst. Biotechnol. 31 (2003) 339-355.

27. M.M. Bradford, A rapid and sensitive method for the quantification of microgram quantities of protein utilizing the principle of protein-dye binding. Anal. Chem. 72 (1976) 248-254.
28. B. Özer, E., Akardere, E.B., Çelem, S. Önal, Three-phase partitioning as a rapid and efficient method for purification of invertase from tomato. Biochem. Eng. J., 50 (2010) 110115.

29. A., Şen, M., Eryılmaz, H., Bayraktar, S., Önal, Purification of $\alpha$-galactosidase from pepino (Solanum muricatum) by threephase partitioning. Sep. Purif. Technol. 83 (2011) 130-136.

30. A., Sharma, M.N. Gupta, Purification of pectinases by threephase partitioning, Biotechnol. Lett. 23 (2001) 1625-1627.

31. A.V., Narayan, M.C., Madhusudhan, K.S.M.S. Raghavarao, Extraction and purification of Ipomoea peroxidase employing three-phase partitioning. Appl. Biochem. Biotechnol. 151 (2008) 263-272.

32. J., Szames, E. Kiss, Three-phase partitioning of crude protein extract. J. Colloid Interface Sci., 170 (1995) 290-292.

33. R., Garg, N. Thorat, Nattokinase purification by three-phase partitioning and impact of t-butanol on freeze drying. Sep. Purif. Technol. 131 (2014) 19-26.

34. C., Dennison, L., Moolman, C.S., Pillay, R.E. Meinesz, t-Butanol: nature's gift for protein isolation. S. Afr. J. Sci. 96 (2000) 159-160

35. D., Martinez-Maqueda, B., Hernandez-Ledesma, I., Amigo, B., Mirales, J.A. Gomez-Ruiz, Extraction/fractionation techniques for proteins and peptides and protein digestion. Proteomics in Foods, Springer, US, Boston, MA, 2013, pp. 21-50..

36. G.M., Rather, M.N., Gupta, Three phase partitioning leads to subtle structural changes in proteins. Int. J. Biol. Macromol. 60 (2013) 134-140.

37. C., Wang, H., Wang, R., Ma, P., Shi, C., Niu, H., Luo, P. Yao, Biochemical characterization of a novel thermophilic $\alpha$-galactosidase from Talaromyces leycettanus JCM12802 with significant transglycosylation activity. J. Biosci. Bioeng. 121 (2016) 7-12.

38. J.G., Ferreira, A.P., Reis, V.M., Guimaraes, D.L., Falkoski, S. F., Fialho, S.T., Rezende, Purification and characterization of Aspergillus terreus $\alpha$-galactosidases and their use for hydrolysis of soymilk oligosaccharides. App. Biochem. Biotechnol. 164 (2011) 1111-1125.

39. G.S.,. Anisha, R.P., John, P. Prema, Biochemical and hydrolytic properties of multiple thermostable $\alpha$-galactosidases from Streptomyces griseoloalbus: Obvious existence of a novel galactose-tolerant enzyme. Process Biochem. 44 (2009) 327-333.

40. L.D., Fialho, V.M., Guimaraes, C.M., Callegari, A.P., Reis, D.S., Barbosa, E.E., de L. Borges, M.A., Moreira, S.T. de Rezende, Characterization and biotechnological application of an acidic $\alpha$-galactosidase from Tachigali multijuga Benth. Seeds. Phytochem. 69 (2008) 2579-2585.

41. M.M., Gote, M.I., Khan, D.V., Gokhale, K.B., Bastawde, J.M. Khire, Purification, characterization and substrate specificity of thermostable $\alpha$-galactosidase from Bacillus stearothermophilus (NCIM-5146). Process Biochem. 41 (2006) 1311-1317. 